Durning, B

Benefits of coupling environmental assessment and environmental management to aid disaster risk reduction and management.

Durning, B (2014) Benefits of coupling environmental assessment and environmental management to aid disaster risk reduction and management.Journal of Environmental Assessment Policy and Management, 16 (3). pp. 1-25.

doi: $10.1142 / S 146433321450029 x$

This version is available: https://radar.brookes.ac.uk/radar/items/f95d22e9-e78e-4db7-9284-9bfa5d67e418/1/

Available on RADAR: February 2016

Copyright (C) and Moral Rights are retained by the author(s) and/ or other copyright owners. A copy can be downloaded for personal non-commercial research or study, without prior permission or charge. This item cannot be reproduced or quoted extensively from without first obtaining permission in writing from the copyright holder(s). The content must not be changed in any way or sold commercially in any format or medium without the formal permission of the copyright holders.

This document is the post print version of the journal article. Some differences between the published version and this version may remain and you are advised to consult the published version if you wish to cite from it. 


\section{Benefits of coupling environmental assessment and environmental management to aid disaster risk reduction and management}

The tsunami which devastated Japan in 2011 highlighted the consequences of natural disasters on an area considered to be 'best prepared' for such an event. Learning from the direct environmental, social and economic impacts and temporally and spatially displaced indirect global impacts, is important. When seeking to identify and mitigate the impact of proposed developments the process is carried out from two distinct perspectives:' before' and 'after' implementation with environmental impact assessment and environmental management the main 'instruments' on either side. Drawing on examples from financial institutions and disaster response agencies, this paper explores the theory that coupling the two 'instruments' can aid disaster risk reduction and management. It concludes that there is no simple answer and that further research is needed to inform practice.

Keywords: environment, assessment, management, disaster, risk, Japan.

\section{Introduction}

In March 2011 the Tohoku region of Japan suffered the consequences of a devastating tsunami triggered by a massive earthquake off its eastern coast. As an island located in a very geologically active area, such events are not uncommon and the area is subject to earthquakes and tsunamis on a regular basis (Mori et al, 2011). Consequently the region had 'substantial' defense mechanisms in place against such events, including early warning systems, emergency response systems, planning restrictions and soft and hard physical tsunami barriers (UNEP, 2012). The region was considered to be 'one of the areas best prepared for a tsunami' (Mori et al op cit). However, the earthquake was one of the five most powerful every recorded across the globe since monitoring began in 1900 (UNEP, op cit) and the geographical consequences of the tsunami was similarly unprecedented: 'On the Sendai Plain, the maximum inundation height was $19.5 \mathrm{~m}$, and the tsunami bore propagated more than $5 \mathrm{~km}$ inland. Along the ... coast from about 50 to $200 \mathrm{~km}$ north of Sendai, the narrow bays focused the tsunami waves, generating the largest inundation heights and run-ups' (Mori et al 2011).

Learning from such events is important, not only in order to be able to better 'prepared' for such events, but also to understand how anthropogenic factors can increase or decrease the risk associated with them. For example, Mori et al (op cit) note that whilst aspects of local tsunami behavior are influenced by the physical geography and hydrodynamics of the area, they also 'relate to the locations of buildings, streets, and other elements of urban infrastructure'. As part of the learning process from the Tokohu event, a four day Japan-UK joint workshop on 'Policy Integration between Environmental Assessment and Disaster Management' was held at the Chiba University of Commerce, Ichikawa, Japan in December 2012. The aim was to share international thoughts on how impact assessment can contribute to disaster risk reduction and management. The workshop also gave delegates the opportunity to see, first hand, the consequence of such events through a two day site visits to parts of the Tohoku region. This paper is based on a presentation made to the workshop in December 2012. 


\section{The need to consider risk}

Humanity is faced with the consequences of risks associated with an expanding global population, modeled to rise from 6.9 billion in mid-2011 to 9.3 billion in 2050 and to 10.1 billion by 2100 (United Nations, 2011), with the largest expansions in Africa and Asia. This expansion is happening in parallel with the desire for a more urban model of living, resulting in land pressures and rapid urbanization. Pelling (2012) in considering the risks associated with a move towards more urban living, notes 'the rapidly growing numbers of people who live in urban slums and squatter settlements with limited access to basic services and political capital but who often are highly exposed to risk in all its forms... [including]... environmental hazard' (Pelling, 2012 p145). However, the 'global north' ${ }^{1}$ should not be complacent and consider this warning of the consequences of rapid urbanization as only relevant to countries in the 'global south'. For example, the population in the UK is projected to rise from 63.7 million in 2012 to 77 million by 2050 (ONS, nd) which will result in more people in some urban areas (often coinciding with the most vulnerable in terms of socio-economic status) having increased exposure to certain environmental hazards (Houston et al, 2011). Environmental hazards are variable in nature and origin (Table 1) and therefore consideration of the risks is vital for all developments, regardless of the location.

$<<$ table 1 here $>>$

When seeking to identify and mitigate the impact of a proposed development or change in land use, the process is often carried out from two distinct perspectives:' before' and 'after' implementation with environmental impact assessment (EIA) and environmental management (EM) (involving the development of systems and processes) being the main instruments on either side. Both have a slightly different purpose. Weston (2004) gives a useful and broad summary of the central purpose of EIA as being 'to provide decision makers and the public with a systematic, comprehensive and objective assessment of the environmental consequences of an action' (and there is increasing interest in the role of EIA in disaster risk reduction and recovery (Gore and Thomas, 2014)). In contrast to EIA, which aims to identify and mitigate impacts ex ante development, EM involves the actual implementation of systems, plans and processes to manage and reduce the impact ex post during the construction and operational phase of development. Whilst EIA is a legislated process in most countries (although there can and are variations in the requirements of the legislated process in different countries), the development of EM systems, plans and processes is generally voluntary and a self-regulated process (unless conditioned by a decision making authority).

\section{Evolving EIA and EM}

Coincidentally, the law/guidance for both tools is now, in certain quarters, being adjusted towards a more strategic direction and the need for risk considerations becoming more explicit. The European Union (EU) EIA Directive has recently been revised (EU, 2014) and has to be transposed into EU Member law by 2017. The revised Directive includes the requirement for EIA to include disaster risk consideration for certain developments:

\footnotetext{
${ }^{1}$ Global North and Global South are usually used as interchangeable terms with 'Developed' and 'Developing' Counties (so some 'Global North' countries are actually in the southern hemisphere e.g. Australia)
} 
'to consider their vulnerability (exposure and resilience) to major accidents and/or disasters, the risk of those accidents and/or disasters occurring and the implications for the likelihood of significant adverse effects on the environment';

and to ensure that follow up and monitoring is carried out of the development:

'mitigation and compensation measures are implemented and that appropriate procedures are determined regarding the monitoring of significant adverse effects on the environment resulting from the construction and operation of a project, inter alia, to identify unforeseen significant adverse effects'.

Unlike EIA, there is no legislative requirement to produce systems or plans for EM. One of the most popular self-regulating standards for developing systems for environmental management is published by the International Organisation for Standardisation (ISO) and is commonly known as 'ISO14001' (ISO, 2004). However, whilst ISO 14001 is considered a key tool for managing the environmental impact in many organisations and industries (there were 285844 systems certified to ISO14001 globally in 2012 (ISO, 2012)), uptake of the standard shows global variations (Neumayer and Perkins, 2004). Other 'standards' for environmental management also exist (these are often industry or country specific - see for example the discussions in Haughey et al, 2005). However, ISO14001 provides a useful generic process based framework for self-regulation which can be applied to any sector, industry or organisation. The ISO 14001 guidance is also undergoing revision with the revised guidance scheduled for publication in 2015. Proposed changes include the need for more 'strategic' (as oppose to purely operational) management involvement and also consideration of 'environmentally-related organizational risks... and local, regional or global environmental conditions that can affect, or be affected by, the organization' (ISO, 2013).

Discussion on the theoretical closer integration and coupling of EIA and EM tools and processes has been evident in the literature over a number of years (see Durning et al, 2012). With both tools now evolving to have more explicit requirements for strategic risk based consideration there is an opportunity for exploring how a possibly seamless coupling of the tools will aid disaster risk reduction (DRR) in an era of rapid urbanization. This paper explores this theory by first considering how disaster risk considerations can be addressed in environmental assessment and management and postulates the need for the adoption of a more adaptive management focus. It then explores the similarities and differences to the EIA and EM processes and theoretical integration, including integration of an adaptive management approach. The applicability of the theoretical integration is then discussed drawing on examples of practice where assessment and management are coupled, particularly in relation to risk reduction. Finally the paper concludes with a consideration of suggestions on the implications for future research to inform practice.

\section{Disaster risk and environmental assessment and management}

The consequences of a sudden event (e.g. earthquake, tsunami) or extreme event (e.g. flood, fires) can be catastrophic. The humanitarian consequences of such events are often the most visible or made the most visible through comprehensive coverage by global news and social media. These media pressures can influence decision making and prompt humanitarian agency input (Audett and Paquette, 2012), although it is noted that these agencies often 'perceive environmental concerns to be of secondary importance' (Spalling and Vroom, 2007). However, the environmental consequences of sudden and extreme events 
can be equally catastrophic, particularly as long term impacts can be significant (such as the irreversible pollution of land, surface and groundwater and consequential effect on ecosystem services).

\section{Environmental consequences of a disaster}

One of the most environmentally 'visible' consequences of a disaster is the sudden generation of large amounts of waste (which needs to be managed in the short to medium term). The Tohoku tsunami in March 2011 caused devastation in three prefectures (Iwate, Miyagi and Fukushima) on the eastern side of Japan. According to the UNEP (2012) nearly 16,000 people died and over 380,000 buildings collapsed or half collapsed. This resulted in the generation of over 22 million tons of waste across the three prefectures. In one city alone (Ishinomaki City) an estimated 6.15 million tons of debris was generated, equivalent to 103 years of solid waste production in that city in 'normal' circumstances (UNEP, 2012 p. 10).

In addition to the significant volume of waste that can be generated by a disaster (and which therefore has to be managed in the short to medium term), a consequence of 'debris' waste generated by tsunami, is that the waste becomes mixed (combining potentially hazardous and non-hazardous, combustible and noncombustible, organic and non-organic) and is moved not only inshore, but also offshore. This can have potentially significant indirect impacts, which can be spatially and temporally displaced: the US National Oceanic and Atmospheric Administration (NOAA) reported on debris waste from the Japan 2011 event being washed ashore on the west coast of North America. They reported a 'floating dock' washed ashore in Oregan in 2012, which 'carried a biofouling community that included over 90 marine species that were not native to the West Coast of North America. Some of these species were known to be invasive and could cause ecosystem and economic harm' (NOAA, 2013, p8). The NOAA noted that, based on modeling of winds and ocean currents 'the bulk of the [Japan Tsunami Marine] debris is likely still dispersed north of the Hawaiian Islands' (op cit, p.7) and may be expected to impact the islands in 2014 (i.e. two years after the event).

Sudden and extreme events also cause significant economic impact: the economic consequence of the 2011 Japan tsunami was estimated at 210billionUSDollars. The cost of managing the waste element was significant: for Ishinomaki City, which had to deal with 103years of waste being generated in one day, the estimated cost for debris management was 262.5millionUSDollars (UNEP, 2012). Toshiaki Yoshioka, a member of the UNEP task force observed: 'due to a shortage of land, waste management in Japan is a challenge even during normal periods...the entire operation [to manage disaster debris is] extremely challenging, both technically and financially' (UNEP, op cit, p.9).

With such potentially major consequences of disasters, both spatially and temporally, consideration of risk is an important factor ex ante and ex post development. The following section of the paper considers this further by exploring the theory of DRR and the relationship with EIA and EM.

\section{Disaster risk reduction (DRR) and environmental assessment and management}

Disaster risk can be defined as the existence of a hazard (i.e. 'a potential threat to humans and their welfare' (Smith, 2001)), multiplied by vulnerability i.e. 'people's susceptibility to loss, injury or death' or 'susceptibility to harm' (Wisner et al, 2012). The extent to which a community is exposed to a hazard e.g. 
by nature of their geographical location or by having little or no coping strategies in place, increases their vulnerability and hence the potential for disaster to occur.

DRR is defined by the United Nations International Strategy for Disaster Reduction (UNISDR, 2009) as 'the concept and practice of reducing disaster risks through systematic efforts to analyse and manage the causal factors of disasters, including through reduced exposure to hazards, lessened vulnerability of people and property, wise management of land and the environment, and improved preparedness for adverse events'. Ways to achieve this can be through risk mitigation e.g. by preventative action and building social resilience. In an era of rapid urbanization, DRR can be considered a theoretical concept which when applied in policy making can bring benefit to urban communities. It can act as a 'champion' for ensuring there is an integrated or holistic approach to policy making and a centrality of procedure leading to 'distributional justice in governance and decision-making' (Pelling, 2012, p.147). Pelling also notes that consideration of inter-generational impact of disaster is also often omitted. A pertinent example of this comes from the small Japanese fishing town of Onagawa (Miyagi prefecture) which was impacted by the 2011 tsunami. Pre tsunami, the population of the town was 10,400 (with eighty percent of the population living in the area subsequently devastated by the tsunami). Over 800 people died or were still missing nine months after the disaster. The majority of those who died were women in their 60 s and 70 s, possibly affected by lack of mobility once the significance of the tsunami $(16 \mathrm{~m}$ high) became apparent. This left the community with an older generation dominated by males, who were more conservative in their views on reconstruction proposals than younger generations (Yaginuma, 2012).

Destructive sudden events can act as a trigger for migration events: between 2008 and 2012 'over 140million people [globally] were on the move as a consequence of natural hazards' (IOM, 2013, p.16). The migrants are identified as 'overwhelmingly' young people which can alter the demographics of their community of origin that lose 'their productive population and become disproportionately inhabited by a relatively vulnerable population (i.e. one composed of mostly old people, single mothers and children)' (op cit, p.20). The town of Onagawa experienced this migration event: the extensive sudden devastation of the town and loss of the significant fishing industry in March 2011, coupled with the relatively slow rate of reconstruction (which in 2014 is still ongoing), caused economic migration to occur: by November 2012 the population had reduced to 8000 (Yaginuma, 2012) and reduced further to 7300 by May 2014 (Onagawa Town, 2014)

Overcoming these consequences is challenging: Pelling (2012) hypothecates that having 'open and inclusive urban management' and coordinating of a number of elements of urban governance (including development planning, development regulation, risk reduction, emergency management, and particularly the inclusion of community participation in governance) would counter some of the policy omissions. Pelling suggests this openness, inclusivity and coordination of governance would aid reduction of not only socio-economic but also environmental risk. Echoing the observations of Audet and Paquette (2012) Pelling notes that 'non-human entities' (ie environmental and ecological aspects) are often not considered or given 'superficial' attention in DRR and post disaster reconstruction activities.

Many of the aspects noted by Pelling (such as community (and wider) stakeholder participation in decision making and the need to consider environmental impacts) are addressed through the EIA process, but it is interesting to note that Pelling does not identify EIA as one of the urban governance processes that can assist in reducing the omissions in DRR. However, whilst research on the role of EIA as a tool for urban 
governance may be missing in parts of the academic literature, the benefits of integrating DRR in environmental assessments is identified in practice related literature (e.g. Benson, 2007 and DEWGA, 2008, pvii).

Benson (2007) identifies five factors for 'critical success' in incorporating DRR into environmental assessment:

- Sufficient information

- Early assessment

- Adequate monitoring

- Awareness of the benefits of assessing disaster risk as part of the environmental assessment process

- Supportive environmental policy

These key 'success' factors include consideration of not only assessment (emphasis added) but also the management aspect: 'environmental policies and related safeguard compliance policies should require satisfactory analysis and related management of disaster risk as part of the environmental assessment process' (Benson op cit p.7).

A challenge for the inclusion of disaster risk considerations in the assessment process is deciding how to mitigate risks, as elimination of all risk is likely to be impossible: 'although many risks are potentially avoidable, global environmental change and uncertainty about future hazardous events, together with the central role played by human failings in all disasters make the total elimination of hazard an unrealistic task' (Smith, 2001, p. 340). One approach might be to adopt the 'precautionary principle' at all times. However, many authors have noted that use of the precautionary principle is not straightforward and comes with the risk of misapplication, potentially leading to a 'paralysis in decision making' (Sustein, 2005 cited in Bacon, 2012 p.164). Balint et al (2011) also observe 'the relative strength of precautionary arguments tends to rise with the perceived severity of possible future harms' (p. 67). They cite the scientific uncertainty of the scale of anthropogenic influences on climate change and the severity of the adverse effects of climate change as an example of this: those opposing the imposition of regulation call for more research to reduce the uncertainties whilst those following the precautionary principle call for regulation stating that the likely adverse effect are serious enough to justify regulation despite uncertainties.

Another, theoretical approach, would be to use adaptive environmental assessment and management processes. Early work on environmental assessment advocated this: 'unless big disasters can be completely eliminated (which we take to be impossible) there remains the problem of designing our institutions and artifacts to cope with their occurrence' (Holling, 1978, p.138). Holling further argued that the need to be adaptive is demonstrated when failure or disaster occurs as 'there exists a serious trade-off between designs aimed at preventing failure and designs that respond and survive' (p138). Balint et al (2011) also promote adaptive management for managing 'wicked' environmental problems (i.e. those for which there is no obvious solution) although couch that the process needs to be iterative, analytical and participatory, as well as adaptive.

Incorporating adaptive management elements into EIA has been discussed previously in the wider EIA literature. The following section of the paper discusses some of the similarities between EIA and EM 
(using ISO14001 as a generic framework for an EM system) and considers the existing literature on adaptive management in EIA, proposing a theoretical framework for integration.

\section{EIA and EM similarities and adaptive management theoretical integration}

It is advocated that in seeking to incorporate DRR and disaster preparedness (e.g. pre disaster planning) into any urban development, there should be the assumption that the environmental assessment and management aspects be linked (or coupled). The need for this 'continuation' and ongoing of process has been advocated over many years:

'if assessment continues into the future, then prediction loses its status as a goal and assessment merges into environmental management. Prediction and traditional 'environmental impact assessment' suppose that there is a 'before and after' whereas environmental management in an ongoing process (Holling, op cit p.133)

EIA is a mature process used in most parts of the globe to aid decision making (ensuring that the decision is better formed) and the formulation of development actions (by anticipating environmental challenges at an early stage in the process design) and to act as an instrument for sustainable development (though the avoidance of environmental damage) (Glasson et al 2012). These outcomes tend to be associated with legislated EIA process, but (as discussed later in the paper) EIA is also a process which can be used outwith of legislative requirements for risk management (for example by major financial institutions such as World Bank, European Bank for Reconstruction and Development (EBRD)). Where the process is used as a way of managing financial risk, the management commonly extends beyond the initial assessment into management of impact during construction (through the use of systems such as environmental management plans) and into operational management (through use of e.g. environmental management systems, resettlement plans, auditing and monitoring).

EM frameworks are used to manage the environmental impact of any sector, organization or industry. Whilst the policy or regulatory regimes applicable to the EIA and EM processes can vary, they also have many similarities (summarized in Table 2).

$<<$ Table 2 here $>>$

The EM frameworks apply a systems approach with interconnected elements using the 'Plan, Do, Check Act' feedback mechanisms. Noble (2000) proposed that EIA could be strengthened by the inclusion of systematic elements into its process (and become Adaptive Environmental Assessment and Management (AEAM)) and observed that 'the adaptive approach reflects a conclusion that EIA strategies should be facilitated through an approach that allows adjustments to changing events, decisions and circumstances'. Noble did not advocate that all EIAs had to include elements of adaptive management, but rather recommended their inclusion 'when complexity, uncertainty and risks are associated with management options'.

Noble identified a number of key elements of adaptive management: 
- Adaptive approach uses available data at different timescales to construct a range of alternative response models to impact - therefore the proposed development could start with vague premises which are refined through the process

- Temporal boundaries need to be clear and the importance of post approval monitoring needs to be recognized

- Need for a monitoring component in the management system to provide feedback

- Mitigatory goals and objectives should be adaptive to changing conditions as assessing and managing dynamic complex environmental systems

- EIA monitoring and mitigatory processes need to be able to adapt to change

- Participant and stakeholder workshops are incorporated early in the planning and preliminary assessment stages

Noble also identified that legislative frameworks could provide a hindrance as having to renegotiate monitoring or mitigatory processes may be a challenge. Therefore there needs to be 'institutional flexibility and collaboration' to ensure success of the monitoring plan and adaptive management as a whole.

The benefits of adaptive management and EIA were also considered by Morrison-Saunders et al (2004). However, they use a broader definition for adaptive management than that initially proposed by Holling in 1978 and instead use it to mean 'changing project and environmental management activities in response to either actual impacts that have occurred or to avoid potential impacts' (p155). They advocated a focus on environmental outcomes and identified the following key aspects:

- Impact management objectives should be established during EIA scoping stage

- Involvement of proponents of developments, as they are responsible for the EM stage

- Involvement of local communities - particularly in follow up programmes

- Legal follow up requirements need to be flexible rather than prescriptive

As discussed previously, Benson (2007) indentified five key 'success criteria' for incorporating DRR into environmental assessment (sufficient information, early assessment, adequate monitoring, awareness of the benefits of assessing disaster risk as part of the environmental assessment process, supportive environmental policy). In order for close coupling of EIA and EMS to aid DRR and recovery, a number of other key factors can also be identified from wider literature, many of which echo the points made by Noble, Morrison-Sauders et al and Benson on the key features. These are discussed in the following section.

\section{Information exchange, knowledge brokers, feedback loops and capacity development}

Sanchez (2012) describes EIA as a 'knowledge-intensive' activity, with a number of different actors generating data, compiling information and using and creating knowledge (including consultants, proponents, decision making authorities). He proposes that achieving a transition from project planning through to management needs a mix of managerial tools (such as EIA and EM - although he suggests the tools to be used are not limited to just these) and the need for human 'capacity development' e.g. through information sharing and knowledge generation within and between the different actors. 'Capacity development' extends the concept of capacity building to focus not just on building existing strengths and 
resources within individuals, communities, organisations etc but to 'encompass all aspects of creating and sustaining capacity growth over time. It involves learning and various types of training, but also continuous efforts to develop institutions, political awareness, financial resources, technological systems and wider social and cultural enabling technologies' (UNISDR, 2009). Capacity development potentially means developing new systems and ways of working.

Others have identified the importance of information sharing and 'knowledge-brokers' and feedback loops to the impact assessment process. Bond et al (2010) emphasis the importance of regular information exchange (in relation to successful implementation of EIA in a multidisciplinary team) whilst Sheate and Partidário (2010) identify the importance of 'knowledge-brokers' as key to ensuring relevant information is shared or transferred from its source to appropriate place. Sinclair et al (2008) and Fischer et al (2009) discuss the importance of strategic assessments and greater stakeholder engagement as influential factors in the development of feedback loops. Raissiyan and Pope (2012) and Mynhneer (2012) (both reflecting on the need for closer EIA and EM coupling in the oil and gas industry, which is an industry that has many risks in many areas of operation) identify the need for the human actors in the process to be conversant with 'each other's terminology and techniques, as well as the language of hazard identification and risk assessment' (Raissiyan and Pope (2012) p.125). Gore and Fischer (2014) note the lack of technical expertise in EIA in developing countries as a barrier to implementing EIA during disaster recovery.

Mynheer (op cit) further identifies the complex corporate factors that can often place barriers to technical conversations and also the consequence of temporal aspects - with issues of disjoint in timing between the EIA and subsequent EM development being one of the challenges to coupling. Mynheer proposes the need for proactive communication and consultation between key stakeholders (in his model these comprise the internal stakeholders ie the various elements within the oil companies plus external stakeholders (see Figure 1) and (echoing others) also the need for a key knowledge broker (in his model this is the Project Manager who is based within the proponent organisation).

$<<$ Figure 1 here $>>$

The work of Raissiyan and Pope and Mynheer adds to a larger body of theoretical work on models for the integration of EIA and EM (e.g. Eccleston 1998, Perdicoulis and Durning, 2007). Adaptive assessment and management provides a further theoretical strand to the EIA and EM coupling. This is shown in Figure 2 which is based on the theoretical model of Perdicoulis and Durning (2007) with the addition of the adaptive aspects from Noble (2000) Morrison-Saunders et al (2004).

$<<$ figure 2 here $>>$

\section{Coupling to aid risk reduction}

There is a small body of published examples of successful practical examples of coupling EIA and EM (e.g. Barnes and Lemon, 1999 and Marshall, 2002 and 2004 which are some early examples - see also case study chapters within Perdicoulis et al 2012 for more recent examples). Marshall and Fischer (2006) extended the coupling by suggesting that the addition of a 'tiered' strategic environmental assessment process, linking through to project assessment and then into management, could be used as a strategic 
planning model in private sector companies. The following section of the paper discusses other practical examples of how assessment and management are coupled as a continuous process, particularly in relation to disaster preparedness, DRR and disaster recovery.

\section{Environmental assessment and management to manage financial risk}

Much of the key literature on the need to incorporate DRR (and disaster preparedness) into environmental assessment processes appears to be based on, or is influenced by, input from organizations that work with major financial institutions and funders of development e.g. Benson (2007) draws on examples from the African Development Bank and Caribbean Development Bank. The practice of these institutions is influenced by the need for risk reduction in their financial investments rather than solely for the achievement of sustainable low disaster risk urban development. However, they provide a useful example of how the coupling of EIA and EM is used to identify, and therefore reduce and manage, risk.

Some major financial institutions such as the World Bank (part of the World Bank Group which lends money to countries) and the International Finance Corporation (IFC) (which is part of the World Bank Group which finances private sector investment) (Conley and Williams, 2011) explicitly see risk reduction as a significant part of their way of working. The World Bank (2011) state that they 'routinely' require risk assessments 'for projects involving handling, storage, or disposal of hazardous materials and waste, the construction of dams, or major construction works in locations vulnerable to seismic activity or other potentially damaging natural events.'

The IFC first adopted its 'Environmental and Social Safeguard Policies' and it's Disclosure Policy in 1998 (Broderick, 2012). These was superceded in 2006, when the IFC applied its Policy and Performance Standards on Social and Environmental Sustainability to all investment projects to minimize their impact on the environment and on affected communities (IFC, 2006). There are eight Policy and Performance Standards (PSs) addressing:

1. Social and Environmental Assessment and Management System

2. Labour and Working Conditions

3. Pollution Prevention and Abatement

4. Community Health, Safety and Security

5. Land Acquisition and Involuntary Resettlement

6. Biodiversity Conservation and Sustainable Natural Resource Management

7. Indigenous Peoples

8. Cultural Heritage

IFC (2006) states the aim of PSs 1 (Social and Environmental Assessment and Management System) is to 'establish the importance of:

(i) integrated assessment to identify the social and environmental impacts, risks, and opportunities of projects

(ii) effective community engagement through disclosure of project-related information and consultation with local communities on matters that directly affect them

(iii) the client's management of social and environmental performance throughout the life of the project'. 
Broderick (op cit) observes (based on personal experience of working on IFC funded projects) that 'the monitoring and follow up requirements of the PSs lead in a tangible way to better outcomes for all stakeholders involved'.

The above relate to requirements of a specific financial investment organisation (i.e. branches of the World Bank Group). In 2002 a small number of other financial investment organisations, in consultation with the IFC, established a set of financial industry 'standards' for determining, assessing and managing social and environmental risk in project financing, based on the IFC/World Bank guidelines (Conley and Williams, 2011). These are called the Equator Principles (EP) and were subsequently revised in 2006 and in 2013. There are now 70 institutions who have 'signed up' to the EP (Equator Principles, 2011). The EP consist of ten principles:

Principle 1: Review and categorization

Principle 2: Environmental and social assessment

Principle 3: Applicable environmental and social standards

Principle 4: Environmental and social management system and Equator Principles Action Plan

Principle 5: Stakeholder engagement

Principle 6: Grievance mechanism

Principle 7: Independent review

Principle 8: Covenants

Principle 9: Independent monitoring and reporting

Principle 10: Reporting and transparency

Based on interviews with various actors involved in the EPs (including NGOs who act as unofficial 'regulators' to the EP process), Conley and Williams (2010) state 'there does seem to be emerging consensus that the EPs are significant to the banks as a strategy for minimizing a variety of potentially material risks'.

\section{Use by disaster response agencies}

The examples from the financial institutions highlight how, by including the requirements for EM processes (monitoring and auditing and the use of management plans and systems to monitor and manage impacts during the operational phase of development and beyond) these organisations are reducing their risk exposure. This is a theme echoed by UNISDR (2004) and DEWGA (2008) who also refer to the use of environmental management plans and operational systems to continue the preparedness of risk from assessment into operational management e.g.: 'a well-maintained inventory of chemicals and hazardous substances used by local industries, and their proper labeling, will ensure that, during a disaster event, the risks that such materials pose to communities living nearby can be mitigated by proper isolation, handling and segregation' (DEWGA, 2008 p.26).

The need for information management and exchange between key stakeholders (and the vulnerable communities) in order to build a 'culture of disaster prevention and resilience' has been identified in a number of reports and strategy documents on DRR (e.g. ISDR, 2007). The United Nations High Commissioner for Refugees (UNHCR) handbook on refugee operations and environmental management 
(2002) provides guidance on environmental assessment, planning and monitoring. It emphasizes the importance of 'baseline' data being collected before an emergency happens 'as this greatly facilitates subsequent impact assessment' (p. 25) and also identifies the importance of environmental monitoring and evaluation to 'determine the appropriateness and effectiveness of environmental interventions' (p.31). The importance of involving local communities in DRR and management of the environmental impacts of the consequence of disasters is also recognized. The handbook notes the 'best way to monitor environmental rehabilitation activities on the ground is to empower local communities to undertake participatory monitoring and evaluation exercises themselves' (p.31). However, community involvement may not always be forthcoming and success requires 'a detailed understanding of the incentives and motivations for refugees or local communities to become involved' (UNHCR, op cit).

An example of the use of environmental impact assessment as a tool for environmental management through inclusion of management and policy recommendations is given in a Government of Kenya/donor agency report available on the Danish Refugee Council (DRC) website; published in 2010 the report documents a socio-economic and environmental impact assessment of the Dadaab refugee complex located in Kenya's NE province. The complex comprises three camps which were first established in 1991 and accommodates 270,000 predominantly Somali refugees. The remit of the study was to assess the environmental and socio-economic impact of the camps on the surrounding area, to identify mitigation and enhancement opportunities and to provide recommendations for improving 'the sustainable presence of the refugees' (DRC, op cit). The recommendations for management of the impact focused on supporting and expanding locally based community management options, including recognizing the role of community and 'clan-based institutions' in managing and mediating and conflict over natural resources. It is interesting to note that the terms of reference for the study include the requirement to consider not only the 'here and now' but to consider future scenarios and the likely impacts over the next 5-10 years.

\section{Conclusions and further development}

As future scenarios indicate a growing global population and growing demand for urban living, there is increasing potential for exposure of vulnerable communities to natural hazards and the potential for disasters to occur. The aim of this paper was to explore how coupling EIA and EM can aid in disaster preparedness, DRR and in reducing the environmental impact of the direct and indirect consequences of disasters.

Adaptive management, comprising assessment and management which is a continuous process, could in theory, allow for disaster preparedness to be incorporated into urban developments by ensuring that risk mitigation measures or disaster preparedness actions are identified during assessment process and incorporated into management practices. EIA is not identified by the urban governance community as a key tool for DRR, yet is used as a tool in financial risk reduction in project financing and also used by a range of organisations to identify management actions and policies during the post disaster phase. The need for adaptive approach to assessment of projects that have risk or uncertainties related to them has been identified in the literature for many years (e.g. Noble 2000). The need for EIA to be 'flexible' in terms of the stricture with which it is applied in order to be useful tool has also been recognized in the literature (e.g. Spaling and Vroom, 2007). The possible ways to integrate EIA and EM have also been addressed both in theory and in practice in the EIA literature. However, a simple answer to how to successfully couple the two processes seems elusive, particularly for those developments were EIA is part 
of the legislated process and only used as a tool to aid the decision making ex ante development. This paper has sought to identify a number of factors which could aid the coupling:

1. The development of EM actions should be seen as part of the EIA process, rather than a completely separate process. This would require knowledge development in practitioners and ways of ensuring knowledge and information sharing processes occur.

2. A 'knowledge broker' is key to the knowledge and information sharing process; the role of proponent is also important.

3. Communication and feedback loops need to be in place

4. The role of communities in the management aspect is needed

Morrison-Saunders et al (2004) observed that the incorporation of adaption management will come through improvements in EIA practice and technological innovations. As recognition of the need for consideration of risk and the management of risk is increasing, this has implications for practice and for research which can inform practice. Questions to be addressed will come from exploring the factors which aid the coupling and exploring key aspects such as: what is the role of knowledge networks and the motivation of knowledge brokers to proactively seek to bridge the divide; what would motivate the 'communities' (that are a key factor) to be involved, what is the appearance and substance of these communities and how could their input be sustained. Such questions need to be addressed to inform practice to deliver future sustainable urban developments.

\section{Acknowledgements}

The paper benefited from the comments made on earlier drafts by David Valler, Thomas Fischer, Martin Broderick and an anonymous referee.

\section{References}

Audette F and Paquette F (2012) Lessons from the 2011 Japanese Earthquake and Tsunami for Canada's Humanitarian Sector. Report to the Humanitarian Coalition from the Canadian Research Institute on Humanitarian Crisis and Aid (OCCAH).

Bacon, C.M (2012) Disaster risk and sustainable development in Wisner, B, Gaillard, J.C. and Kelman, I (eds) The Routledge Handbook of Hazards and Disaster Risk Reduction. Routledge: London and New York

Balint, P J, Stewart, R E, Desai, A and Walters L C (2011) Wicked Environmental Problems: managing uncertainty and conflict. Island Press: Washington, Covelo and London

Barnes J and Lemon D (1999) Life-of-project environmental management strategy: case study of the Confederation Bridge project, Canada. Journal of Environmental Assessment Policy and Management 1 (4) $429-439$

Benson C (2007) Tools for mainstreaming disaster risk reduction: Environmental Assessment - guidance note 7. Provention Consortium 
Bond A, J, Viegas, C.V. Coelho, C. C, dS. R., Selig, P M (2010) Informal knowledge processes: the underpinning for sustainability outcome in EIA? Journal of Cleaner Production 18 6-13

Broderick M (2012) ESIA effectiveness through links to EMS. In Perdicoulis, A, Durning, B and Palframan L (eds) Furthering Environmental Impact Assessment: towards a seamless connection between EIA and EMS. Edward Elgar: Cheltenham UK and Northampton MA USA

Conley J M and Williams C A (2011) Global banks as global sustainability regulators? The Equator Principles. Law and Policy 33 (4) 542-575

DEWGA (2008) Linking disaster risk reduction, environment management and development practices and practitioners in asia pacific region: a review of opportunities for integration. Working Paper of the Disasters Environment Working Group for Asia

DRC (2010) In search of protection and livelihoods: socio-economic and environmental impacts of Dadaab Refugee Camps on host communities. Available at www.drc.dk [17 June 2014]

Durning, B, Palframan, L and Perdicoulis A (2012) Chapter 1 - Introduction' in Perdicoulis, A, Durning, B and Palframan L (eds) Furthering Environmental Impact Assessment: towards a seamless connection between EIA and EMS. Edward Elgar: Cheltenham UK and Northampton MA USA

Eccleston C (1998) Strategy for integrating NEPA with EMS and ISO14001. Environmental Quality Management 7(3) 9-17

EU (2014) Directive 2014/52/EU of The European Parliament and of the Council of 16 April 2014 amending Directive 2011/92/EU on the assessment of the effects of certain public and private projects on the environment

Equator Principles (2011) Equator Principles: environmental and social risk management for project finance. Available at www.equator-principles.com [16 June 2014]

Fischer, T B, Kidd, S. Jha-Thakur, U, Gazzola, P and Peel, D (2008) Learning through EC directive based SEA in spatial planning? Evidence from the Brunswick Region in Germany. Environmental Impact Assessment Review 29 421-428

Glasson, J Therivel, R and Chadwick A (2012) Introduction to Environmental Impact Assessment (4th Ed). Routledge: London and New York

Gore T and Fischer T B (2014) Uncovering the factors that can support and impede post-disaster EIA practice in developing countries: the case of Aceh Province, Indonesia. Environmental Impact Assessment Review 44 67-75

Haughey K.F.D., Tait, S.V and O'Connell, M.J. (2005) Qualitative evaluation of three 'evironmental management systems' in the New Zealand wine industry. Journal of Cleaner Production 13, 1175-1187 
Holling, C.S. (ed) (1978) Adaptive environmental assessment and management. The Blackburn Press, Caldwell, New Jersey.

Houston, D., Werritty, A., Bassett, D., Geddes, A., Hoolachan, A and McMillan, M (2011) Pluvial (rainrelated) flooding in urban areas: the invisible hazard. Report to the Joseph Rowntree Foundation by the University of Dundee. Available at http://www.jrf.org.uk/sites/files/jrf/urban-flood-risk-full.pdf [17 June 2014]

IFC (2006) Performance standards on social and environmental sustainability. Available at http://www.ifc.org/wps/wcm/connect/Topics_Ext_Content/IFC_External_Corporate_Site/IFC+Sustainab ility/Sustainability+Framework/Sustainability+Framework+$+2006 /$ Performance+Standards+and+Guidance+Notes/ [17 June 12014]

IOM (2013) Compendium of IOM activities in disaster risk reduction and resilience. International Organization for Migration. Available at www.iom.int [17 June 2014]

ISDR (2007) Hyogo Framework for Action 2005-2015: Building the Resilience of Nations and Communities to Disasters. United Nations International Strategy for Disaster Reduction, Geneva

ISO (2004) ISO 14001 Environmental Management Systems: Requirements with guidance for use. International Organization for Standardization

ISO (2012) The ISO survey of management system standard certification (1999-2012). Available at http://www.iso.org/iso/home/standards/certification/isosurvey.htm?certificate $=\mathrm{ISO} \% 209001 \&$ countrycode $=\mathrm{AF}$ [17 June 2014]

ISO (2013) Revision of ISO 14001 Environmental management systems - Requirements with guidance for use. Available

at: http://www.iso.org/iso/1n1000_iso_14001_revision_information_note_update_november2013.pdf [17 June 2014]

Marshall, R. (2002) Professional practice: developing environmental management systems to deliver mitigation and protect EIA process during follow-up. Impact Assessment and Project Appraisal 20 (4) 286-292

Marshall, R (2004) 'Can industry benefit from participation in EIA follow-up - the Scottish Power experience'. In Morrison-Saunders, A and Arts J (eds) Assessing impact: handbook of EIA and SEA follow-up London:Earthscan

Marshall R and Fischer T B (2006) Regional electricity transmission planning and SEA: the case of the electricity company ScottishPower. Journal of Environmental Planning and Management 49 (2) 279-299

Mori, N., T. Takahashi,T. Yasuda, and H. Yanagisawa (2011), Survey of 2011 Tohoku earthquake tsunami inundation and run-up, Geophys. Res. Lett.,38, L00G14, doi:10.1029/2011GL049210 
Morrison-Saunders, A., Jenkins B. and Bailey, J. (2004) EIA follow up and adaptive management. In Morrison-Saunders A and Arts J (eds) Assessing impact: handbook of EIA and SEA follow-up. Routledge

Mynheer G J (2012) Bridging the gap between EIA and EMS within the oil and gas (upstream) industry. MSc Dissertation, Oxford Brookes University

Neumayer E and Perkins R (2004) What explains the uneven take-up of ISO14001 at the global level?: a panel-data analysis. Environment and Planning A 36 (5) 823-839

NOAA (2013) Severe marine debris event report: Japan tsunami marine debris. Overview and update to congress, August 2013. Available at: http://marinedebris.noaa.gov/sites/default/files/Japan_Tsunami_Marine_Debris_Report.pdf [17 June 2014]

Noble B.F. (2000) Strengthening EIA through adaptive management: a systems perspective. Environmental Impact Assessment Review 20 97-111

Onagawa Town (2014) Community website: 'Onagawa Town - full of smile and bring back'. Available at http://www.town.onagawa.miyagi.jp/ [17 June 2014]

ONS (nd) Age structure of England and Wales 1968-2087. Office for National Statistics. Available at http://www.ons.gov.uk/ons/interactive/uk-national-population-projections---dvc3/index.html [17 June 2014]

Pelling, M (2012) Hazards, risk and urbanisation' in Wisner, B, Gaillard, J.C. and Kelman, I (eds) The Routledge Handbook of Hazards and Disaster Risk Reduction. Routledge: London and New York

Perdicoulis, A., \& Durning, B. (2007). 'An alternating-sequence conceptual framework for EIA-EMS integration'. Journal of Environmental Assessment Policy and Management, 9(4), 385-397.

Perdicoulis, A, Durning, B and Palframan L (2012) Furthering Environmental Impact Assessment: towards a seamless connection between EIA and EMS. Edward Elgar: Cheltenham UK and Northampton MA USA

Raissiyan B and Pope J (2012) EIA-EMS link from the oil and gas industry. In Perdicoulis, A, Durning, B and Palframan L (eds) Furthering Environmental Impact Assessment: towards a seamless connection between EIA and EMS. Edward Elgar: Cheltenham UK and Northampton MA USA

Sanchez, L E (2012) Information and knowledge management. In Perdicoulis, A, Durning, B and Palframan L (eds) 'Furthering Environmental Impact Assessment: towards a seamless connection between EIA and EMS'. Edward Elgar: Cheltenham UK and Northampton MA USA

Sheate, W. R. and Partidario, M R (2010) Strategic approaches and assessment techniques - potential for knowledge brokerage towards sustainability. Environmental Impact Assessment Review 30 278-288 
Sinclair, A J, Diduck, A and Fitzpatrick P (2008) Conceptualising learning for sustainability through environmental assessment: critical reflections on 15 years of research. Environmental Impact Assessment and Review 28 415-428

Smith K (2001) Environmental hazards: assessing risk and reducing disaster ( ${ }^{\text {rd }}$ ed). Routledge: London and New York

Smith K and Petley D N (2009) Environmental hazards: assessing risk and reducing disaster (5 ${ }^{\text {th }}$ ed). Routledge: London and New York

Spalling H and Vroom B (2007) Environmental assessment after the 2004 tsunami: a case study, lessons and prospects. Impact Assessment and Project Appraisal 25 (1) 43-52

Sunstein C (2005) Laws of fear: beyond the precautionary principle. Cambridge University Press: Cambridge

United Nations (2011) World Population Prospects: The 2010 Revision. United Nations Department of Economic and Social Affairs, Population Division. New York.

UNEP (2012) Managing post-disaster debris: the Japan experience. United Nations Environment Programme Available at http://postconflict.unep.ch/publications/UNEP Japan post-tsunami debris.pdf [17 Jun 2014]

UNHCR (2002) Refugee operations and environmental management. A handbook of selected lessons learned from the field ( $2^{\text {nd }}$ Edition). Engineering and Environmental Services Section, UNHCR, Geneva, Switzerland

UNISDR (2004) Living with Risk: A global review of disaster reduction initiatives (Volume 1). United Nations Publication, Geneva, Switzerland

UNISDR (2009) Terminology on disaster risk reduction. International Strategy for Disaster Reduction. Available at www.unisdr.org [17 June 2014]

Weston J (2004) EIA in a risk society. Journal of Environmental Planning and Management, 47 (2) 313325

Wisner, B, Gaillard, J.C. and Kelman, I (2012) Framing disaster in Wisner, B, Gaillard, J.C. and Kelman, I (eds) The Routledge Handbook of Hazards and Disaster Risk Reduction. Routledge: London and New York

World Bank (2011) OP4.01 Environmental Assessment, Annex A - definitions. Available at http://web.worldbank.org [17 June 2014]

Yaginuma, T (2012). Presentation to delegates at the Japan-UK workshop on Policy Integration between Environmental Assessment and Disaster Management by Mr Toshiaki Yaginuma, Section of Reconstruction, Onagawa Town, Japan, $2^{\text {nd }}$ December 2012. 
Table 1 - Major Categories of Environmental Hazard (adapted from Table 1.2 in Smith and Petley, 2009)

\begin{tabular}{|l|l|}
\hline Major categories of environmental hazard \\
\hline $\begin{array}{l}\text { Natural hazards } \\
\text { (extreme geophysical and biological } \\
\text { events) }\end{array}$ & - - Atmospheric e.g. tropical cyclones \\
& - Hydrologic e.g. floods, drought \\
\hline Technological hazards & - Biologic e.g. wildfires \\
(major accidents) & - Transport e.g. air accidents \\
& - Industrial failures e.g. explosions and fires \\
& - Unsafe public buildings e.g. structural collapse \\
\hline $\begin{array}{l}\text { Context hazards } \\
\text { (global environmental change) }\end{array}$ & - Hazardous materials e.g. storage, transport \\
& - International air pollution \\
& - Environmental degradation e.g. deforestation \\
& - Sand pressures e.g. intensive urbanization \\
\hline
\end{tabular}


Table 2: A comparison of 'typical' EIA and EMS elements and requirements for development or change of land use (Adapted from Table 1.2 in Durning et al 2012)

\begin{tabular}{|c|c|c|}
\hline Characteristics & $\begin{array}{l}\text { 'Typical' EIA process (for developments or } \\
\text { change of land use) }\end{array}$ & $\begin{array}{l}\text { 'Typical' EM framework (based on } \\
\text { ISO14001) }\end{array}$ \\
\hline Goal & $\begin{array}{l}\text { To provide environmental protection by } \\
\text { ensuring environmental considerations are } \\
\text { integrated into decision-making for } \\
\text { developments (as part of legislated process) }\end{array}$ & $\begin{array}{l}\text { To provide environmental protection by } \\
\text { identifying impacts. Through systems for } \\
\text { continuous improvements, to reduce these } \\
\text { impacts. }\end{array}$ \\
\hline Scope & $\begin{array}{l}\text { Proposed projects deemed likely to have } \\
\text { significant environmental effects }\end{array}$ & $\begin{array}{l}\text { Applies to all activities within the specified } \\
\text { site or organisation }\end{array}$ \\
\hline $\begin{array}{l}\text { Organisations } \\
\text { directly involved }\end{array}$ & $\begin{array}{l}\text { Proponents intending to apply for permission to } \\
\text { develop a project }\end{array}$ & $\begin{array}{l}\text { Voluntary approach which can be used by any } \\
\text { sector, organisation or industry that wishes to } \\
\text { manage its environmental impacts in } \\
\text { accordance with a recognised standard. }\end{array}$ \\
\hline $\begin{array}{l}\text { Personnel directly } \\
\text { involved }\end{array}$ & $\begin{array}{l}\text { Varies - consultants appointed by proponent; } \\
\text { some are prepared in-house by project } \\
\text { proponent }\end{array}$ & $\begin{array}{l}\text { Consultancy support may occasionally be } \\
\text { sought in setting up the EMS but they are } \\
\text { usually implemented by in-house personnel } \\
\text { with day-to-day responsibility for } \\
\text { environmental issues }\end{array}$ \\
\hline $\begin{array}{l}\text { Public } \\
\text { participation }\end{array}$ & $\begin{array}{l}\text { Public consultation on the Environmental } \\
\text { Statement; public may also be involved at other } \\
\text { stages }\end{array}$ & $\begin{array}{l}\text { Organisation can decide whether to } \\
\text { communicate externally about its significant } \\
\text { environmental aspects }\end{array}$ \\
\hline Planning & $\begin{array}{l}\text { A scoping stage allows for the EIA to be } \\
\text { planned in terms of the issues to be assessed and } \\
\text { the methods by which this will be achieved. }\end{array}$ & $\begin{array}{l}\text { An Initial Environmental Review identifies } \\
\text { and evaluates significant aspects and impacts. } \\
\text { An Environmental Policy is produced based } \\
\text { on the issues identified and the commitments } \\
\text { the organisation wishes to make. }\end{array}$ \\
\hline Documentation & $\begin{array}{l}\text { Environmental Statement summarising the } \\
\text { findings of the EIA produced for a set point in } \\
\text { time (the consenting process). }\end{array}$ & $\begin{array}{l}\text { Environmental Policy developed, maintained } \\
\text { and communicated. Evolves according to } \\
\text { changing circumstances. Various procedures } \\
\text { required to be documented and maintained. }\end{array}$ \\
\hline Significance & $\begin{array}{l}\text { Broadly classed as characteristics of the impact, } \\
\text { characteristics of the development and location } \\
\text { of the development. }\end{array}$ & $\begin{array}{l}\text { Broadly include environmental impact, legal } \\
\text { requirements and stakeholder concern. }\end{array}$ \\
\hline Mitigation & $\begin{array}{l}\text { Environmental statement includes a description } \\
\text { of the measures to prevent, reduce and where } \\
\text { possible offset any significant adverse effects on } \\
\text { the environment }\end{array}$ & $\begin{array}{l}\text { Provides a system for ensuring that mitigation } \\
\text { measures are implemented, for example the } \\
\text { activity they relate to may be identified as a } \\
\text { "significant aspect". They may be formally } \\
\text { monitored, audited and reviewed. }\end{array}$ \\
\hline Monitoring & $\begin{array}{l}\text { Requirements can vary - individual proponents } \\
\text { may be obliged to do so through the consenting } \\
\text { authority making conditions. }\end{array}$ & $\begin{array}{l}\text { Requirement to maintain and implement a } \\
\text { procedure to monitor and measure the } \\
\text { significant impacts of the operation. In } \\
\text { practice this includes monitoring of resource } \\
\text { used and regular internal audits. }\end{array}$ \\
\hline
\end{tabular}




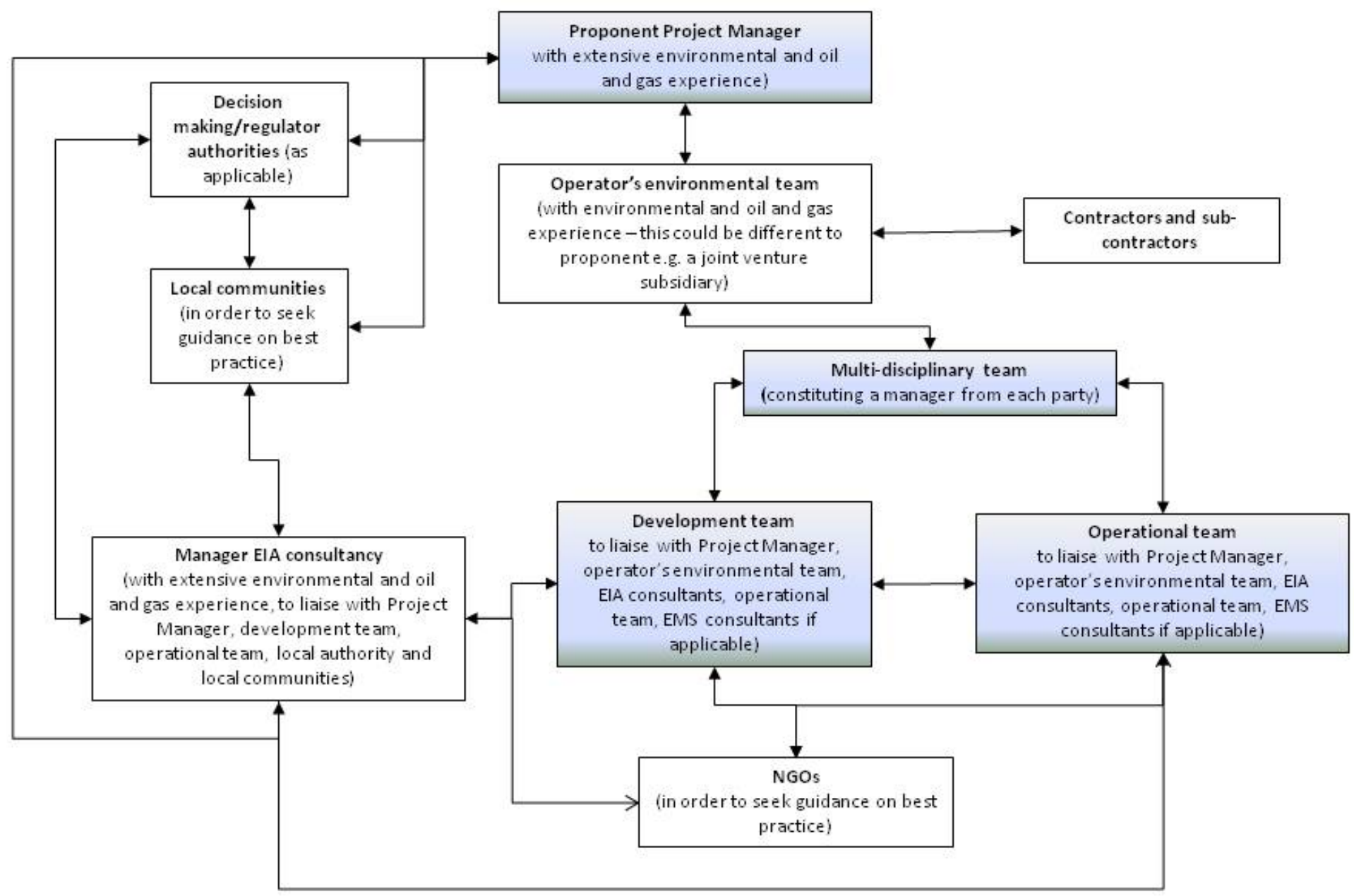

-Arrows suggest consultation and communication between te ams.

- Shaded boxes represent the te ams belonging to the operator 


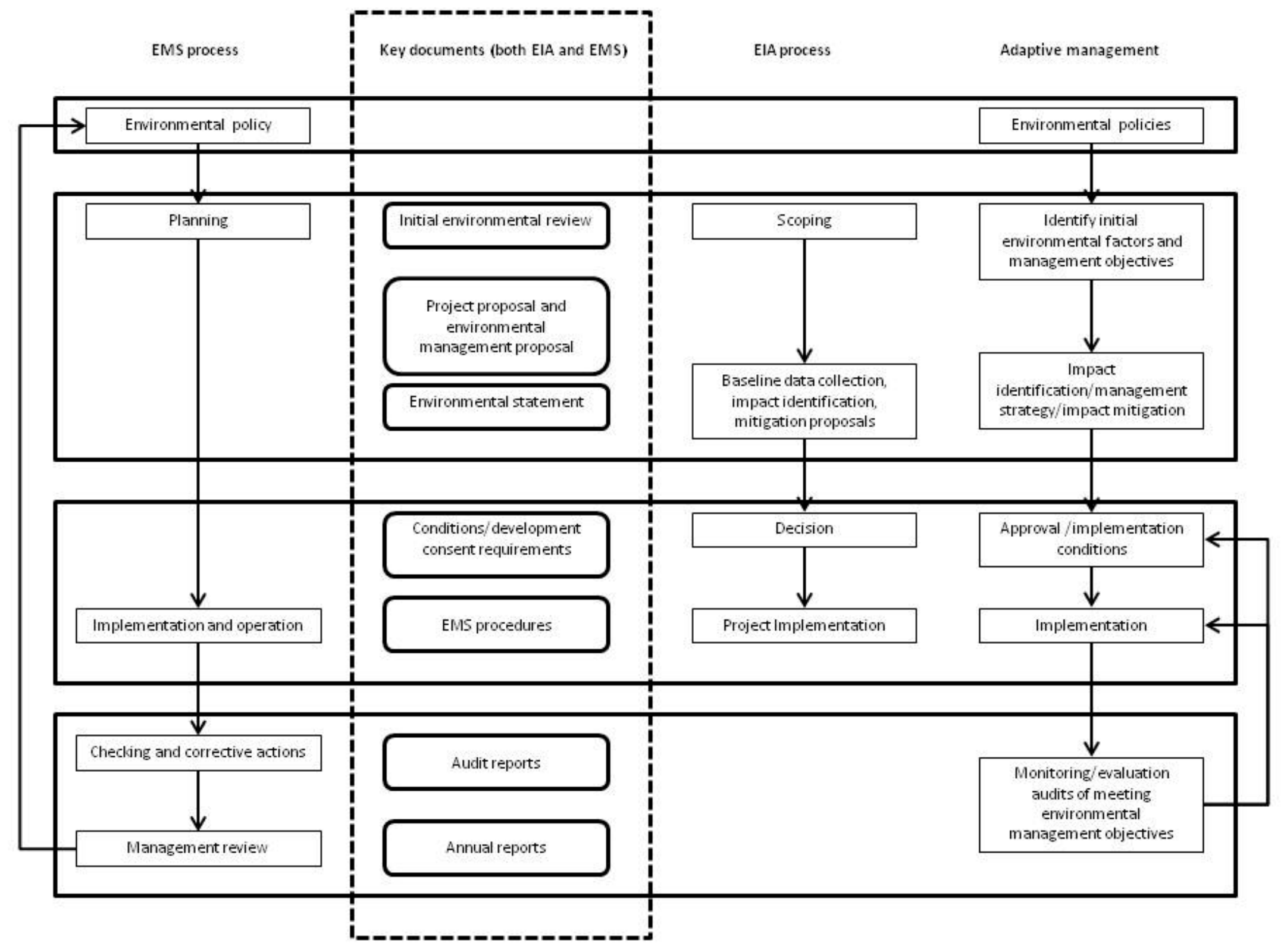

